ressel who had prescribed for himself. In the cases treated in the hospital, however, no cure was effected, although in certain of them there was some temporary benefit." 2 I considered that the benefit obtained in these cases was slight becarse the ferment contained in the muscle was probably destroyed in the digestive canal, in the same way that trypsin is destroyed by pepsin. I attempted to make a glycerine extract of muscle and to obtain from it a glycolytic ferment which might be injected subcutaneously, but as my attempts to isolate one were not successful, and there were difficulties in the way of carrying on treatment by subcutaneous injections, I did not pursue the subject further. The treatment which has lately come so much in vogue in treating diseases by giving the thyroid, pancreas, bone marrow, testicles, or supra-renal capsules, either in the form of the raw organs or of extracts made from them is, I think, essentially the same as that which I tried twenty years ago in the treatment of diabetes, and in all cases the action of the remedy probably depends upon the presence of a ferment, or, as it is now called, an enzyme. I am, Sirs, yours faithfully,

Stratford-place, W., April 24th, 1894. T. LAUDER BRUNTON.

\section{"THE ACTION OF ASPARAGUS ON THE KIDNEY,"}

To the Editors of THE LANCeT.

SIRS,-Three years ago I sent a short communication to THE LANCET ${ }^{3}$ requesting the opinion of the profession on this subject. I therein stated that in spite of books declaring asparagus to be a diuretic I had observed that the very contrary was its action. Four letters came in reply, written by medical men. Three of them stated that from direct observation they had ascertained the inhibitory action of asparagus on the function of the kidneys, so that frequently only a third of the normal quantity of urine was secreted after eating this vegetable. The fourth gentleman said he had no knowledge of his own, but believed asparagus to be a diuretic, as he had always understood it to be so. I am reminded of the subject by hearing once more this vegetable recommended to a patient as a diuretic. The question of its action in the economy is of little importance when it is so universally eaten and approved of, but it is one of interest in connezion with the history of medicine as a science and art. In other sciences knowledge has grown from small beginnings, so that they have a solid foundation and superstructure; but the practice of medicine has existed from the remotest ages and was born of superstition. Consequently a iarge part of our advance has been by getting rid of and overthrowing error. I have on my shelves a "herbal," published about a hundred years ago, describing the value of a vast number of plants which are now discarded as useless; but that a positive error, and one the very reverse of the truth, as regards the action of a well-known vegetable should still be propagated in books is a most remarkable fact, and, as regards the whole subject of therapeutics, a very sad one.

I am, Sirs, yours truly,

Grosvenor-street, April 23rd, 1894. SAMUel Wilks.

\section{"PERIPHERAL NEURITIS." To the Editors of THE LANCET.}

SIRS,-In the "Mirror of Hospital Practice," published on March 31st, a case is reported from the Middlesex Hospital as one of "Peripheral Neuritis of the Sensory Nerves," in which the condition of anæsthesia is quite exactly described as affecting the posterior internal surface of both thighs from the ham and gluteal fold, an area comprising both buttocks and sacrum, the scrotum and penis, the upper part of the calf, and the outer part of the foot. There was also an inability to empty the bladder. In an article published in June, 1892, in the American Journal of Medical Sciences, and fully reproduced in the editorial columns of THE LANCET soon after, the diagrams of which have also recently been reproduced in Brain (winter number, 1893), I believe I proved conclusively that anæsthesia distributed in this manner was absolutely diagnostic of disease, involving either the cauda equina or the spinal cord at and below the level of the fifth lumbar segment of the cord, and that it was never due to lesions of the sciatic nerve,

2 Ibid., Feb. 21st, 1874, p. 22 ?

3 THE LANCET, June 6th, 1891 . which is rarely bilateral, or to multiple neuritis, which uniformly attacks the peripheral parts of the extremities and does not select strips of skin such as described in this case. If the reporter had also considered the fact that in peripheral neuritis, even of very extreme type, there is no affection of the action of the bladder and rectum, while such affection always accompanies lesions of the lower cord and cauda, he would also have hesitated to make such a diagnosis. It was the object of the paper cited to show that by the peculiar distribution of anæsthesia the differential diagnosis between cord and nerve lesions was to be made, and the conclusions reached have been amply confirmed by more recent observations by Head and Thorburn, published in the last three numbers of Brain. These observations must have escapec the notice of the reporter of this case, and I take the liberty of calling his attention as well as that of your readers to them and to their diagnostic importance.

$$
\text { I am, Sirs, yours truly, }
$$

M. ALLEN STARR, M.D.

University Club, Madison-square, New York, April 11th.

\section{"THE PROPOSED NILE RESERVOIR." To the Editors of THF LaNcer.}

Sins,-Being greatly interested in Egypt and its sanitary prospects, I rejoice to see THE LANCHT directing public attention to the proposed Nile reservoir in such an able and impressive manner. The question is without doubt the most important which England has as yet brought forward during her occupation of that country, and it is absolutely incumbent on the authorities that, as you say, the scheme which will, sanitarily speaking, prove the best for the welfare of the inhabitants should be selected. Having some knowledge of Egypt, acquired during a residence of seven years, I venture to offer a few observations, trusting that you will be able to find room for them. The writer of your review of the reports submitted by Mr. Willcocks and Dr. Rogers is, I think, mistaken on one point of cardinal importance. He says: "Moreover, the water in the reservoir will be stored at a time when it is perfectly pure." Now, as I understand the matter, the sluices in the dam of a river-bed reservoir could not possibly be closed before January in each year, by which time all the pare Abyssinian water would longe since have passed away towards the Mediterranean. 'The stock ponded up would necessarily and unavoidably be furnished by the White Nile and be derived from the pestilential regions: of Central Africa, the home of the bilharzia hrmatoba, and many more zooparasites, to say nothing of such diseases as dysentery, typhoid fever, and what are commonly called "fevers." I presume I may take it for granted that I am the "medical writer" alluded to by your reviewer, for I am not. aware that anybody else has written recently on the subject. If so, I hope he will pardon me for saying that I did not, as he: alleges, utilise Dr. Engel Bey's statistics for the purpose of "making a comparison of the mortality of the varions towns." I am perfectly well aware that the Egyptian census of 1882 is untrustworthy, and that comparison of the death-rate between any two towns would be misleading. In the tables which I constructed (of which some little time ago I sent you copies) the death-rate is quite immaterial; whether it appear as 5 per 1000 or 50 per 1000 in no wise affects the point which I am seeking to establish. My object is to show that the death-rate (whatever it may be) rises regularly in all towns that use Low Nile water, and that it is entirely unaffected in towns that depend for their supply during the Low Nile season on water previously stored in cisterns. In Table A I noted the number of deaths by periods. of four weeks for twelve of the principal towns in Lower Egypt during the five years from 1886 to 1890 inclusive. In Damietta and Rosetta alone out of these twelve towns there. was never a rise of mortality during the Low Nile season, whereas in the other ten towns the enhancement of the death-rate took place to a marked degree every year in four towns, four times out of the five years in four more, and three times in the remaining two, which were Alexandria and Damanhour, both fed by the Mahmoudieh Canal. In the aggregate, an increase of mortality equal on the average to. 53 per cent. occurred in the ten towns forty-two times out. of a possible fifty. It is also a remarkable fact that during the same period the deaths exceeded the births thirty-eight times in the ten towns, but not once in either Damietta or Rosetta. The air temperature, on which your reviewer relies, being practically the same in all the twelve towns, the 